\title{
Magyar vállalatok külföldi tőkeberuházásai: helyzetkép a járvány tükrében
}

\author{
Outward Foreign Direct Investments of Hungarian Companies: \\ Their Situation in the Light of the Pandemic
}

Endrödi-Kovács Viktória és Goreczky Péter

https://doi.org/10.47707/Kulugvi_Szemle.2021.4.6

Összefoglaló: A Covid19-járvány világszerte jelentős mértékben csökkentette a külföldre irányuló beruházási kedvet. Ennek ellenére a magyar külgazdasági törekvések között továbbra is nagy hangsúlyt kap a hazai vállalatok tőkekihelyezéseinek a támogatása. A jelen tanulmány célja annak a kiderítése, hogy a pandémia hogyan hatott Magyarország tőkekihelyezỏ vállalataira, miként befolyásolta a küllföldi beruházási stratégiájukat, illetve a válság nyomán változott-e az állami támogatások iránti igény. A tanulmány elkészítése során a módszertani eszközök közül a szekunder adatok elemzésével, illetve a tőkekihelyező magyar vállalatokkal készített interjúkon alapuló esettanulmányokkal éltünk. A fó konklúziónk, hogy a járvány nem befolyásolta érdemben sem a már előkészítési fázisban lévő projekteket, sem a jövőbeni beruházások irá nyát, vagyis összességében a válság nem csökkentette a vizsgálatba bevont cégek küllöldi beruházási hajlandóságát. A tanulmány fő értéke az elvégzett primer kutatás, illetve a választott téma, amelyről eddig csak kevés hazai elemzés született.

Kulcsszavak: magyar OFDI, magyar tőkekihelyezés, koronavírus, állami tá mogatások

Abstract: The pandemic negatively affected the foreign direct investments at global level. However, the outward foreign direct investments (OFDI) of Hungarian companies have still received a growing attention within the external economic strategy. The aim of this study is to show how the pandemic has affected the Hungarian outward investor companies, their investments and whether they need national support in realizing investments. Applied methodological tools include the analysis of secondary data and case studies based on interviews with Hungarian outward investor companies. The main conclusions are that the 


\section{Külïgyi Szemle}

pandemic havent affected significantly the Hungarian OFDIs, their directions and companies' willingness to invest. Main values of this study are the conducted primary research and the topic ilself, about which only a few domestic studies have been published so far.

Keywords: Hungarian OFDI, Hungarian outward inves/ment, coronavirus, state subsidies

\section{Bevezetés}

A rendelkezésre áll statisztikák szerint a pandémia világszerte súlyosan érintette a közvetlen külföldi beruházásokat (Foreign Direcl Investments, FDI): az ENSZ Kereskedelmi és Fejlesztési Konferenciájának (UNCTAD) a legfrissebb jelentése szerint 2019 és 2020 között 35 százalékkal esett vissza a mértéküik. Ez 20 százalékkal alacsonyabb szintet jelent, mint a legutóbbi, 2008-2009-es globális gazdasági világválság idején. Mindez azt mutatja, hogy az 1990-es évek óta nem volt ilyen alacsony a megvalósított közvetlen küllföldi beruházások mértéke (UNCTAD, 2021a).

A tanulmány elkészitése során alapvetően három kérdésre össz pontosítottunk:

- Milyen nehézségeket okozott 2020-ban a magyar vállalatok külföldi termelöüzemeinek a múködésében a Covid19-járvány kitörése?

- Hogyan hatott a pandémia a hazai tőkekihelyező vállalatok küilföldi beruházási stratégiájára, terveire?

- Hogyan változott a válság miatt a külföldi FDI-projektek megvalósításához elnyerhető állami támogatások iránti igény?

A tanulmány alapvetően a fenti kérdések mentén épül fel, és négy fejezetre osztható. A módszertani ismertető utáni első részben bemutatjuk, hogy a pandémia hogyan befolyásolta a kifelé irányuló közvetlen küllföldi tőkeberuházásokat (Ouhward Foreign Direct Investments, OFDIs), kiemelve a folyamatok strukturális vonulatait (motiváció, a globális értékláncokban bekövetkezett változások, digitalizáció, az 
Ipar 4.0 jelentőségének a növekedése). A második fejezetben azt vizs gáljuk, hogy az elérhetô statisztikai adatok alapján hazánkban hogyan alakultak a kifelé irányuló közvetlen külföldi beruházások 2020 eleje óta. A harmadik fejezet öt kiválasztott magyar vállalat külföldi beruházásait elemzi a pandémia tükrében, a levonható általános következ tetésekre összpontosítva. Az utolsó rész pedig arról szól, hogy a magyar állam jelenleg milyen eszközökkel támogatja a vállalatok OFDI projektjeit, és ez hogyan változott a világjárvány hatására.

\section{Módszertan}

Tanulmányunk elkészitése során mind kvantitatív, mind kvalitatív elemzési eszközöket felhasználtunk. A rendelkezésre álló közvetlen küllföldi beruházási adatok elemzését vállalati esettanulmányokkal egészítettük ki, amelyek részletesebb és teljesebb képet mutatnak ar ról, hogyan érintette a válság a magyar tőkekihelyezéseket. A közvet len küllföldi beruházások adatait a Magyar Nemzeti Bank gyújti össze; módszertani megfontolásokból annak a speciális célú vállalatok nélküli, az átfolyó tőkétől és az eszközportfólió-átrendezéstől megtisztított adatsorait használtuk fel. Emellett az UNCTAD legfrissebb adatsorait is figyelembe vettük a kutatás során. A vállalati esettanulmányok elké szitéséhez - részben primer kutatásként - 2021 márciusa és júniusa között félig strukturált interjúkat készítettünk több, a tőkekihelyezés szempontjából releváns hazai vállalattal. Az interjúk elkészítésénél a lehetséges kutatói hibák minimalizálása érdekében, illetve a hatás és etika szempontjából Almadi Sejla $(2018,8$. o.) előirányzásait követtük.

Az esettanulmányokban szereplô öt magyar vállalat (Richter Gedeon Nyrt., Tungsram Operations Kft., MOL-csoport, Agrofeed Kft. és Master Good Kft.) kiválasztásánál arra törekedtünk, hogy a pandémia által eltérő mértékben érintett iparágakban mûködő cégeket kérdezzüink meg, és ez által kapjunk teljesebb képet arról, hogy a válság milyen hatást gyakorolt a hazai vállalatok tőkekihelyezésé re. Mivel valamennyien termelő beruházásokat hajtanak végre (és az ilyen projektek összetettebbek, mint a szolgáltatóipari beruházások 


\section{Külïgyi Szemle}

vagy a vállalati felvásárlások), ezért a velüik készüllt interjúk alapján összeállított esettanulmányok megfelelőek a többféle szempont sze rint történő elemzéshez.

A birtokunkba jutott információk közül terjedelmi korlátok miatt csak a legfontosabbakat szerepeltetjük a tanulmányban, három téma szerinti csoportosításban:

- A pandémia hogyan érintette a vállalat által már megvalósított beruházásokat?

- Megváltoztatta-e a világjárvány a vállalat küllföldi beruházási stratégiáját?

- Változott-e a jövőbeli külföldi beruházásokhoz szüikséges állami támogatások iránti igénye?

A vállalati esettanulmányok kiegészítéseként interjút készitettünk a Magyar Exportfejlesztési Ügynökség (HEPA) munkatársaival, amely során arra kerestük a választ, hogyan változott az államnak a magyar OFDI-projekteket támogató eszközrendszere a pandémia hatására, illetve milyen tapasztalatokat gyújtöttek az elmúlt 1-1,5 évben a hazai vállalatok küllföldi beruházási tevékenységével kapcsolatban.

Természetesen a minta - az alacsony elemszámból adódóan nem tekinthető reprezentatívnak, ugyanakkor fontos információkkal, tanulságokkal szolgálhat a magyar szakirodalom számára arról, hogyan érintette a magyar termelô vállalatok kifektetéseit a pandémia, megfigyelhetők-e a magyar tőkekifektetések terén is a globális szinten előre vetített változások (például a globális értékláncok átalakulása, a digitalizáció növekvő szerepe) és hogyan reagált a magyar beruházás ösztönzô politika a változásokra.

\section{Apandémiahatásaaközvetlen kïlföldiberuházásokra}

A Covid19 jelentős hatást gyakorolt a globális termelésre és az értékláncokra, ami stratégiai kihívások elé állította a vállalatok vezetőit. 2020 során a pandémia megnehezítette a Kínából és más ázsiai országokból származó nyersanyagimportot, sok esetben meg is szakította a 
beszállítói láncokat. A nem létfontosságú termékek és szolgáltatások iránti kereslet visszaesése, a kormányok által bevezetett utazási és egyéb korlátozások, valamint a megbetegedések szintén megnehezítették a vállalatok működését. Globális szinten pedig munkaerőválság alakult ki, amin az egyes országok különböző intézkedésekkel próbáltak enyhíteni (Kumar Luthra, Mangla és Kazançoğlu, 2020).

Ami a közvetlen külföldi beruházásokat illeti, a Covid19-válság csak felerősítette a világban tapasztalható, egyre csökkenő trendet. A korábbi évek növekedését követően az UNCTAD 2020. márciusi becslései szóltak először arról, hogy 5-15 százalékos visszaesés következhet be 2020-ban, illetve 2021-ben a 2019-es szinthez képest (UNCTAD, 2020a). A Gazdasági Együttmúködési és Fejlesztési Szer vezet (OECD) két hónappal később - az optimista forgatókönyv sze rint - már 30 százalékos visszaesést prognosztizált 2020-ra (OECD, 2020). 2020 júniusában (UNCTAD, 2020b) és 2021 januárjában pedig az UNCTAD már 40 százalékos visszaesésról számolt be, és 2021 re is 5-10\%-os visszaesést vetített előre (UNCTAD, 2021b). A közelmúltban megjelent jelentése szerint az UNCTAD 35 százalékos visz szaesést mért 2020-ra vonatkozóan, ami 20 százalékkal alacsonyabb szintet jelent, mint amilyen a 2009-es válság idején volt. Az előrejel zések azt mutatják, hogy 2022-re viszont már növekedés várható, ami a globális értékláncok helyreállásának, a tőkeállomány feltöltésének, a globális gazdaság fellendülésének, illetve az ellenálló képesség érde kében történô szerkezetátalakításnak a következménye lesz. A kilábalás sikere természetesen annak is a függvénye, hogy az egyes államok milyen gazdaságösztönző programokat vezetnek be (UNCTAD, 202la; UNCTAD, 2021b).

Az UNCTAD-nak a pandémia okozta válság elején készített fel mérésekor az általános befektetési trendeket meghatározó száz ve zető multinacionális vállalat több mint kétharmada nyilatkozott úgy, hogy a járvány által leginkább érintett területeken már lassítja a tő kekiadásokat. A többségük alacsonyabb nyereséggel számolt - ami jó val mérsékeltebb újrabefektetett jövedelmet jelent (UNCTAD, 2020a). Az OECD elsősorban a növekvő adósságállománnyal és a csökkenő 


\section{Külïgyi Szemle}

likviditással magyarázta a vállalatok beruházásainak a visszaesését (OECD, 2020). Az IBM Institute for Business Value és az Oxford Economics 2020-as közös felmérése során különböző iparágakból több mint ötszáz vezetőt kérdeztek meg a vállalatuk beruházási terveiről. A válaszok összesítéséből kiderült, hogy a 2020-ra tervezett külföldi beruházásaik 3 százalékát törölték, 13 százalékát pedig elhalasztották. Az ipari termelés ugyanakkor ennél jelentősebb mértékben esett vissza, és csak 2020 decemberére állt helyre világszinten (International Labour Organization, 2021).

A legtöbb külföldi beruházási projektet az autóipari OEM-ek és elektronikai vállalatok törölték vagy halasztották el. A vegyipar, az ITszolgáltatások, a közlekedés, az élettudományok és a gyógyszeripar terüiletén múköőő cégek különböző arányban elhalasztották, de nem törölték azokat. Közép- és hosszú távon ugyanakkor a vállalatok kisebb mértékben (4 és 2, illetve 2 és 1 százalékban) számítanak a be ruházási terveiknek a járvány miatti elhalasztására, illetve törlésére, mint 2020-ban (Dencik, Gijpers, Spee, van Hove és Zaharchuk, 2020, 6. o.). A McKinsey (2021) és az UNCTAD (202la) nemrég viszont arra mutatott rá, hogy a világ vezető nagyvállalatai 2020-ban a Covid ellenére is növekedést tudtak elérni a bőviulés mind a négy dimenzió jában: az alaptevékenységek bővítése, a földrajzi terjeszkedés, az ér tékláncban történô előrelépés, valamint az új tevékenységek felé való elmozdulás terén egyaránt. Emellett a csökkenő bevételek ellenére jelentősen tudták növelni a készpénzállományukat, ami a nagyvállalatoknak a válsággal szembeni jobb ellenálló képességét jelzi.

Összességében jelentősebb mértékben a fejlett országokba irá nyuló FDI csökkent, ami elsősorban a nagyobb tőkeigénnyel és koc kázattal járó zöldmezős beruházásokat érintette. Ez utóbbiak száma leginkább a bányászatban, az energia-, az olaj- és gázszektorban, illetve az ingatlanpiacon és a közlekedési infrastruktúra területén esett vissza. Az ágazati megoszlás tekintetében az ipari beruházások na gyobb mértékben csökkentek, mint a szolgáltatások szektorába irá nyuló FDI. Ez utóbbiban nagy szerepet játszik az IKT-szektor felérté kelődése (UNCTAD, 202la, 9.o.). 
Az UNIDO 2020. augusztusi elemzése szerint a hagyományos gyártó vállalatok, amelyek az év első felében a túlélés érdekében elsősorban a likviditás növelésével voltak elfoglalva, a továbbiakban komolyan meg fogják kérdőjelezni a meglévő ellátásilánc-modelleket. Az alacsony munkaerő-költségű országok termelési helyszínként korábban meglévő vonzereje csökken (hatékonyságra törekvő FDI), az ellá tási láncok esetében pedig a kockázat csökkentése érdekében rövidí tésre és átstrukturálásra lehet számítani. E folyamat eredményeként a vállalatközi és a vállalaton belïli értékláncok jelentősen eltérhetnek. Az FDI-projektek számának az alakulása azt mutatja, hogy mindez már 2020 nyarán elkezdődött (East és Kaspar, 2020).

A tőkeberuházásokat jelentősen befolyásolja a globalizáció mér téke; az utóbbinak a megingása már a Covid-járvány elôtt is megfigyelhető volt az olyan folyamatok révén, mint a kínai-amerikai kereskedelmi háború, a nem vámjellegú új protekcionista intézkedések bevezetése, a brexit vagy az összeolvadásoknak és a felvásárlásoknak az elutasítása nemzeti érdekekre hivatkozva (East és Kaspar, 2020).

David East és Martin G. Kaspar (2020), valamint az IBM (2021) elemzése arra is felhívja a figyelmet, hogy várhatóan most nem lesz visszatérés a korábbi üzletmenethez úgy, ahogyan történt az a fukusimai földrengés vagy a thaiföldi áradások után. Míg a korábbi megingásokat követően a gyártóknak a reális alternatívák hiánya, a lassan fejlődő gyártástechnológia és a változó piaci dinamika miatt a lehető leghamarabb vissza kellett térniük az addigi üzleti modelljük höz, ezek a tényezők napjainkra megváltoztak, és a digitalizáció, az automatizáció, valamint az Ipar 4.0-hoz köthető gyártástechnológiák egyre szélesebb körủ lehetőségeket kínálnak. A hatékonyságkereső motiváció helyett pedig a fejlődő, feltörekvő országokba irányuló be ruházások terén egyre inkább a piackeresés kerül előtérbe. Az érték láncokat úgy építik fel a vállalatok, hogy azok egy újabb válsággal szemben ellenállóbbak legyenek: a regionális értékláncok szerepe nőni fog, és míg a hagyományos üzemek például targoncakölcsönzési lehetőségeket és gépgyártási képességeket kerestek a vállalat közvetlen közelében, addig az intelligens gyártáshoz elsősorban 


\section{Külïgyi Szemle}

adatkutatókra, elektronikai szakemberekre lesz szükség. Ezek a vál tozások azonban nem radikális módon, hanem folyamatosan, idővel gyorsuló fejlődésként fognak végbemenni. A közvetlen hatásuk ugyan akkor a jövőbeni FDI-folyamatokban is érezhető lesz.

Az UNIDO elemzése szerint a vállalatok azonban nem bontják le a méretgazdaságosság elve szerint kialakított telephelyeiket, inkább új vagy helyettesítő beruházások révén fogják követni a jövőbeli ellátási lánc paradigmáját (East és Kaspar, 2020). Ezt az UNCTAD (202la, xii-xiii. o.) legfrissebb jelentése is alátámasztja, amely szerint három lehetséges út létezik a vállalatok számára a globális értékláncok megerősítésére, és közüilük éppen az újratervezésük a legvalószínútlenebb forgatókönyv - elsősorban a költségvonzat miatt. Ehelyett inkább az értékláncmenedzsment hatékonyabb megoldásaira (tervezés és előre jelzés, a rugalmasság növelése) vagy - a kockázat csökkentése érde kében - a fenntarthatóságra helyezik majd a hangsúlyt. Az elemzések szerint a vállalatok várhatóan a termelés biztonságának és fenntart hatóságának a növelésére fognak fókuszálni. Ehhez felgyorsítják az ellátási lánc digitalizációját, robotikával támogatott automatizálást vezetnek be, illetve diverzifikálják az ellátási láncban részt vevő partnereiket (amennyiben ez az adott iparág jellege miatt lehetséges). A jelentések megállapítják, hogy a fenntarthatóság fokozására akkor van lehetőség, ha az országok és régiók kihasználják az új ipari forra dalmat, és legyőzik az egyre növekvő gazdasági nacionalizmust.

A pandémiának a külföldi tőkekihelyezésekre gyakorolt hatásáról eddig kevés tudományos publikáció jelent meg. Ying Fang, Alan Collins és Shujie Yao (2021) a kínai OFDI-adatoknak a Covid19 tükrében történt vizsgálatakor megállapította, hogy a tőkekifektetések 2020 októberéig csökkentek, majd ismét növekedésnek indultak. A beruházási döntésekre a járvány kitörése nem volt jelentős mértékủ hatással, annál inkább a fejlett országoknak a Kínát érintő szankciói, techno lógiai korlátozásai. Ezért a jövőben az ország olyan beruházási cél pontokat keres, amelyek földrajzilag közelebb helyezkednek el hozzá, illetve amelyekkel szoros kétoldalú kereskedelmi és beruházási kapcsolatokat tud ápolni. Smita Shukla és Megha Bansal (2020) arra a 
következtetésre jutott, hogy a pandémia stratégiai szempontból nem befolyásolta az indiai FDI-kihelyezéseket sem.

A magyar szakirodalomban még nem jelent meg tanulmány az FDI-kihelyezések kapesán. Túróczi Imre, Mester Éva és Zéman Zoltán (2020) a magyar gazdaságpolitikának a Covid19-re adott válasz függvényében hozott intézkedéseit elemezte. Tanulmányukban megállapították, hogy a fiskális és monetáris intézkedések a vállalatok túlélését, valamint a válságra jól reagálók növekedésének az elősegítését is szolgálták. Hasonló eredményre jutott Báger Gusztáv és Parragh Bianka (2020) elemzése, amely szerint a magyar járványkezelés sokrétủ, és versenyképességi szempontból az Európai Unión belül az egyik leghatékonyabb volt.

Összességében azonban kijelenthető, hogy a témáról jelenleg ke vés nemzetközi szakirodalom áll rendelkezésre, hazai elemzés pedig nem jelent meg. Tanulmányunkkal ezt a kutatási rést szeretnénk betölteni.

\section{A magyar tôkekihelyezések alakulása a pandémia idószakában}

A koronavírus-járvány hazánkat érdemben 2020 márciusában érte el, amelyre válaszul az üzletmenetet jelentős mértékben befolyásoló korlátozásokat vezetett be a kormány. 2019 a hazai üzleti szféra szempontjából kiemelkedő év volt: a ténylegesen működő vállalkozások száma növekedett, a teljesítménymutatók (a foglalkoztatottak száma, az értékesítésből származó nettó árbevétel, a tényezőköltségen számított hozzáadott érték) pedig szintén emelkedést mutattak minden vállalati létszám-kategóriában. A teljes képhez hozzátartozik ugyanakkor az is, hogy a közepes és nagyvállalatok teljesítménye, termelékenysége jellemzően magasabb szintű. Ezt támasztja alá az a tény is, hogy az egy foglalkoztatottra jutó árbevétel és exportértékesítés esetében a teljesítményük kiemelkedőnek mondható, és növekvő tendenciát mutat (ugyanez a mikro- és kisvállalkozásokról nem állítható) (KSH, 2021 adatai alapján). 


\section{Külïgyi Szemle}

\section{1. ábra'}

A közvetlentőke-befektetések külföldi állománya 2008 és 2020 között (millió USD; bal tengely: Magyarország; jobb tengelv: Európai Unió és a világ)

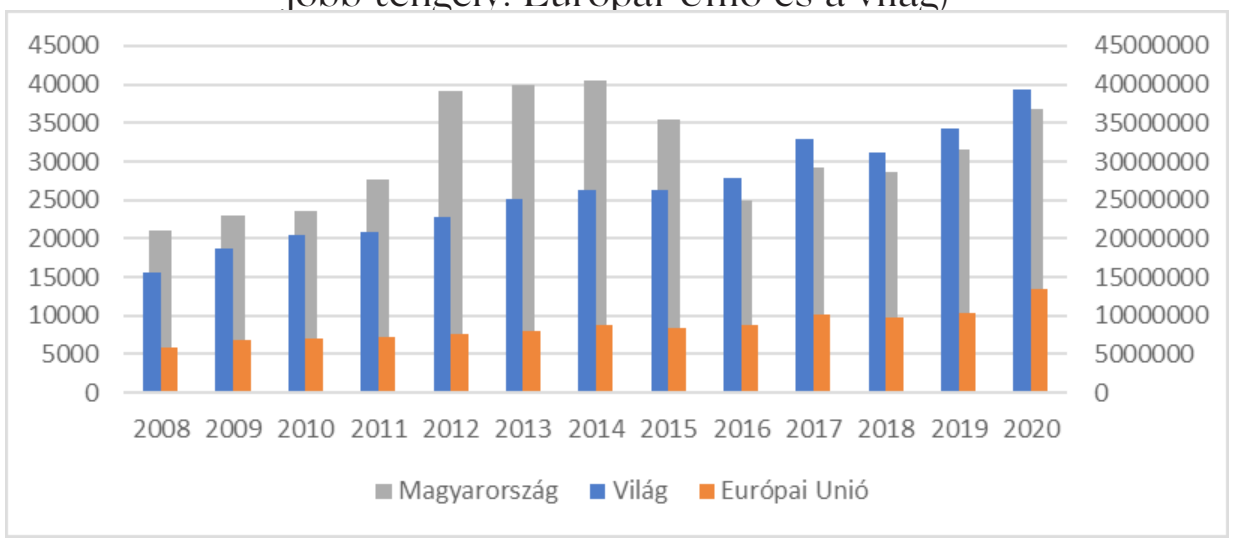

A pandémia előtti években a kifelé irányuló közvetlen külföldi be ruházások állományi adatainak tekintetében is növekedés volt megfi gyelhető, mind globális, mind európai és hazai viszonylatban (1. ábra). Az ábrából az is kiderül, hogy kis és nyitott gazdaságként Magyarország tőkekihelyezési tevékenysége a globális és az európai trendeket követi. Habár a globális áramlás kapcsán az UNCTAD 2019 és 2020 között visszaesést mért (lásd: előző fejezet), az FDI-áramlások összege világszinten pozitív maradt, a küilföldi tőkekifektetések állományi adataiban pedig növekedést figyelhető meg. Ez a megállapítás igaz az Európai Unió esetében is, bár a tagállamok kifektetési tevékenységei között nagy különbségek találhatók. Hazánk akkoriban szintén növelte a külföldi tőkekihelyezéseit. Összességében tehát 2019-ről 2020-ra a közvetlentőke-befektetések külföldi állománya globális, európai és hazai szinten egyaránt növekedett (UNCTAD, 2021c). Az UNCTAD (2021a) elemzése szerint annak ellenére, hogy a válság során a globális FDI-áramlás drasztikusan visszaesett, a nemzetközi termelés továbbra is fontos szerepet játszik a gazdasági növekedés és fejlődés támogatásában. Ez lehet az oka annak, hogy az állományi adatok összességében nem mutatnak csökkenést, sőt a vizsgált időszakban bőviulni tudott a külföldi leányvállalatok felhalmozott tőkekészlete.

1 Forrás: az UNCTAD, 202lc statisztikái alapján. 


\section{2. ábra ${ }^{2}$}

Az OFDI-tranzakciók ágazatonkénti megoszlása és egyenlege (millió forint; az átfolyó tőkétỏl és az eszközportfólió-átrendezéstől megtisztított forgalmak, speciális célú vállalatok nélküil)

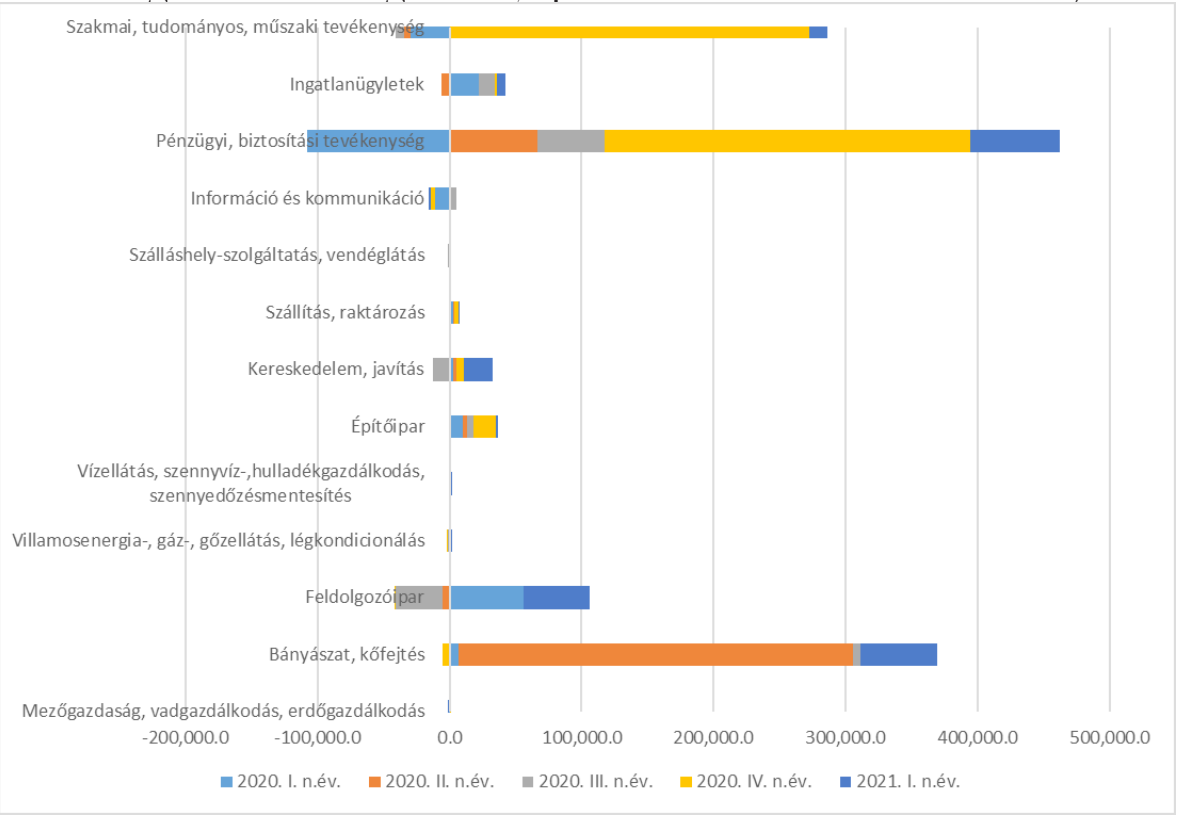

Az ágazati trendek megfigyelésével megállapítható, hogy - a globális folyamatokkal összhangban - 2020. I. negyedéve óta a legtöbb magyar tôkekihelyezés a szolgáltatások szektorában valósult meg, s ezzel megelőzi a feldolgozóipari beruházásokat. Ezen belül is a pénzïgyi és biztosítási, valamint a szakmai, a tudományos és a műszaki tevékenységek emelkednek ki (lásd 2. ábra). Az utóbbi esetében az üzletvezetési, vezetői tanácsadás terén történtek nagyobb beruhá zások, míg - a globális trendekkel ellentétben - az IKT-szektorban nem voltak számottevő mértékủ tőkekihelyezések. A feldolgozóipari beruházások közuil a számítógépek, az elektronikai, illetve optikai termékek gyártása, az élelmiszer-, ital- és dohánygyártás, valamint a kokszgyártás és a kőolaj-feldolgozás emelkedik ki (MNB, 2021). A bányászat és a kőfejtés területein, valamint az építőiparban folytatott

2 Forrás: az MNB, 2021 statisztikái alapján. 


\section{Külïgyi Szemle}

külföldi beruházások szerepe is jelentős volt a megfigyelt időszakban. Ezek a trendek összhangban vannak a korábbi évek magyar OFDIforgalmaival, illetve állományi adataival (MNB, 2021 alapján).

A tőkekifektetések irányát tekintve (lásd 3. ábra) megállapítható, hogy a magyar OFDI legfontosabb célpontjai nem változtak túlságosan a pandémia hatására, vagyis továbbra is azokba az országokba (Horvátország, Szlovákia, Izrael, Bulgária, Románia) áramlik elsősorban a magyar tőke, amelyekben 2019-ben és a korábbi években is a legtöbb beruházás megvalósult, illetve ahol a magyar tőkeállomány értékei a legmagasabbak ( $M N B, 2021$ adatai alapján). Az egyedüli kivételnek Luxemburg tekinthető, amelynek szerepe vélhetően a 2020. IV. negyedévben tapasztalt ágazati trendekkel összhangban értékelődött fel.

\section{3. ábra ${ }^{1}$}

A magyar OFDI 15 vezető célországa 2020 I. és 2021. I. negyedéve között (áramlási adatok, millió forintban)

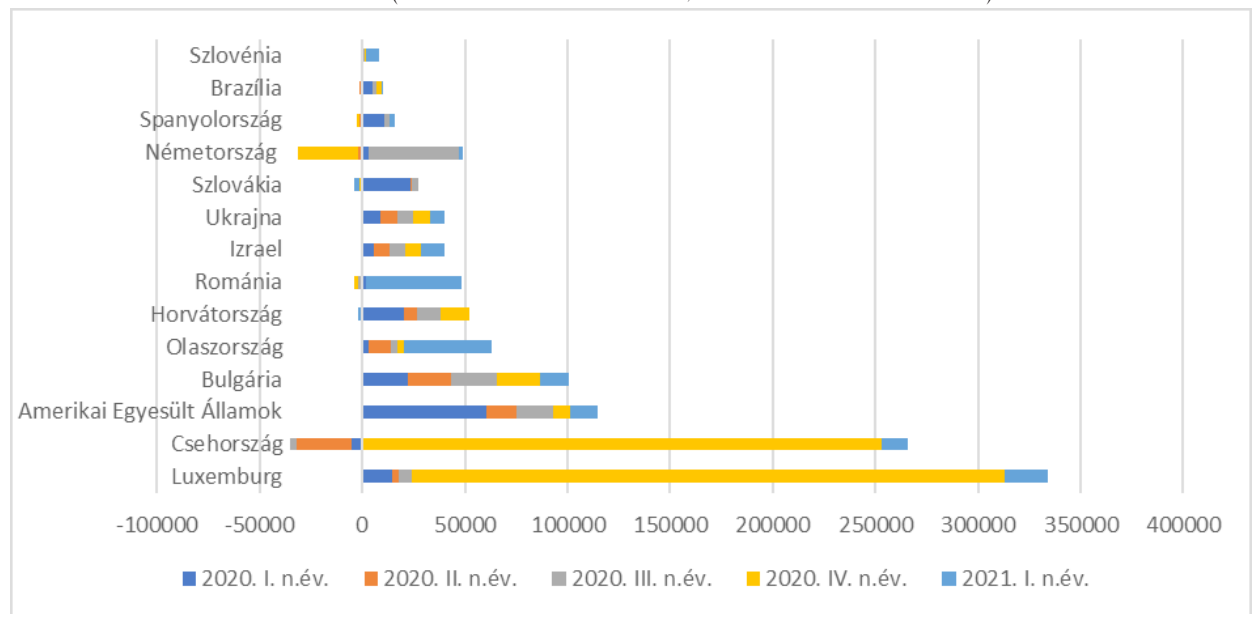

1 Forrás: az MNB, 2021 statisztikái alapján. Megjegyzés: a jelen tanulmányban az adóoptimalizálás szempontjából releváns országok (Hollandia, Ciprus, Írország) eseteit nem vizsgáljuk. 


\section{A Covid-válság és a magyar vállalatok kuilföldi tôkeberuházásai: esettanulmányok}

Ahogyan arról korábban szó volt, a Covid-járványnak a magyar vállalatok küllföldi beruházásaira gyakorolt hatásait termelő vállalatokkal ké szített interjúk révén térképeztük fel. A vizsgálatba a MOL-csoportot, a Richter Gedeon Nyrt.-t, az Agrofeed Kft.-t, a Master Good Kft.-t, valamint a Tungsram Operations Kft.-t vontuk be.

\section{A Covid-járvány hatása a külföldi termelóegységek müködésére}

A Richter Gedeon küllföldi termelőegységeinek működésében a jár vány kitörése ugyanolyan nehézségeket okozott, mint a magyaror szági gyáregységek esetében. A folyamatos készuiltség, a kockázatok csökkentését szolgáló intézkedések, a járvány terjedésének a megelőzését célzó országos és vállalati szintû szabályok megnehezitették a termelőüzemek napi működését. A járvány második és harmadik hullámában a megbetegedések, illetve a beteg dolgozókkal közvetlen fizikai kapcsolatba került elsődleges kontaktok karanténba kerüilése miatt adódtak múködési nehézségek, amelyeket szervezéssel, esetenként hétvégi túlórákkal tudott kezelni a vállalat. A gyártást a járvány miatt nem kellett felfüggeszteni, csúszások is csak ritkán és nagyon minimális mértékben fordultak elő.

A MOL küllföldi termelőegységeinek működésében a járvány ki törését követően az utazási korlátozások okoztak nehézséget, ám a cég rövid idő alatt átállt az online munkavégzésre, amelyhez javarészt már rendelkezésre állt a szükséges infrastruktúra. Sem a norvégiai és pakisztáni lelőhelyek kitermelésének az előkészitését, sem a szüksé ges elemzések elvégzését nem hátráltatja közvetlenül a járvány. Ami a töltőállomás-hálózatot illeti, 2020 tavaszán el tudták látni a határokon túli kutakat is, csupán néhányat kellett rövid időre átmenetileg bezárni az alacsony forgalom miatt. A logisztika és a beszerzés viszont általánosságban megnehezedett. A járvány nem okozott problémákat a helyi partnerekkel történő együttmúködésben, a szerepük ugyanakkor a válság hatására még inkább felértékelődött. 


\section{Külïgyi Szemle}

A Tungsram jellemzően vegyesvállalati formában múködteti a kül földi beruházásait: a helyi partner biztosítja a helyszínt és a mun kaerőt, a magyar cég pedig a technológiát. Az e modell szerint mú ködő szaúd-arábiai összeszerelő üzemben nem állt le a termelés a Covid-járvány miatt, és csúszás sem fordult elő a megrendelések teljesítésében. Érdekességként megemlithető, hogy a termelés a hazai gyáregységekben sem állt le, ugyanakkor előfordultak logisztikai ne hézségek, elsősorban az alkatrész-utánpótlás terén. Az alkalmazottak egy részét át kellett irányítani más területekre, a gyártásban dolgozók létszámát azonban nem kellett csökkenteni. A járvány kitörését követően a online munkavégzésre való átállás két hét alatt lezajlott a vállalat központjában, valamint az összes leányvállalatánál is. Ez nem csupán a munkavállalók védelmét, de a munkamenet zavartalan folytatását is biztosította. A válság ellenére a cégnek sikerült megőriznie a külföldi partnerkapcsolatait, amelyek a jövőbeni OFDI-projekteknél kulcsfontosságúnak bizonyulhatnak.

A koronavírus-járvány Vietnamban is átrendezte a fogyasztói szokásokat, az éttermek és az iskolák bezárása pedig az országban csirkefeldolgozó ïzemet múködtető magyar Master Good Kft. üzletmenetét is negativan érintette. Az üzemet a járvány következtében nem kellett teljesen leállítani ugyan, ám a kereslet visszaesése miatt a termelés csökkentésére volt szüikség: először 60 , majd 30 százalékra. A cégtől kapott információk szerint a heti vágási mennyiség így 2020. április és december között 15.000-20.000 darabra esett vissza, s ennek következtében a heti munkarend megváltoztatása és a napi munkaidő csökkentése is szükségessé vált. A cég vezetői 10-15 százalékos természetes lemorzsolódást tapasztaltak, a távozó munkaeró pótlása azonban nem okozott gondot. Összességében tehát sikerült megórizni a létszámot a vietnami üzemben, nem kellett a válság miatt alkalmazottakat elbocsátani. A hazai vállalatvezetés és a vietnami üzem közti kapcsolattartásban sem mutatkoztak nehézségek, amiben fontos érdemei voltak az üzem vietnami vezetójének.

Az Agrofeed 2016-ban megnyitott oroszországi üzemének a lét rehozását elsősorban a helyi piacon történő érvényesülés motiválta, 
az ottani jelentős regisztrációs korlátok ugyanis megnehezítik a külföldön gyártott takarmánypremix (a teljes értékű takarmány készíté séhez szükséges vitaminokat, ásványi anyagokat tartalmazó koncent rátum) importját. A fő konkurenciának minősülő nyugat-európai vállalatok emiatt többnyire oroszországi gyártóbázissal is rendelkeznek. Az Agrofeed jasznogorszki üzemében dolgozó magyar munkatársak közül a járvány kitörését követően a termelőegység vezetője maradt a helyszínen, a többiek csak októberben tudtak oda visszautazni. A cég értékesítési tevékenységének fontos része a telepi szerviz és menedzsment, illetve az állattartási technológia átadása - e területeken viszont komoly nehézséget jelentettek az utazási korlátozások. A szinte teljesen automatizált termelőizzem működésében ugyanakkor nem okozott fennakadást a válság, a pénzügyi-számviteli-logisztikai folyamatokat pedig Magyarországról is lehetséges ellenőrizni.

A cég oroszországi partnereinek a köre a válság ellenére bővïlt, így az elért árbevétel is növekedett 2020-ban. Ezzel együtt a Covid járvány kitörése és az ellátási láncok zavarai nehézségeket okoztak több alapanyag (például a Távol-Keleten gyártott aminosavak és vitaminok) beszerzésében, a konténerhiány következtében pedig a tengeri szállítmányozás ára a többszörösére nőtt. A magas készletszintnek köszönhetően viszont ezek az anomáliák nem okoztak komoly problémát a termelésben, a cég stabilan el tudta látni a partnereit. Az Agrofeed oroszországi üzemében a válság alatt sem állt le az új rak tárbázis megépítése, így azt három hónap alatt be is tudta fejezni a cég. Egy esetleges nagyberuházást azonban minden bizonnyal megnehezített volna a kiutazások korlátozása.

\section{A Covid-járvány hatása a cégek külfôldi beruházási stratégiájára}

A MOL-csoport esetében a járvány kitörése miatt az eredeti tervek hez képest mintegy 25 százalékkal csökkent 2020-ban az organikus tőkeberuházások teljes értéke. Ugyanakkor a cég a válság ellenére is folytatta a stratégiai jelentőségű küllföldi beruházásai megvalósítását. E projektek közé tartozik az 1,57 milliárd dollár értékű azerbajdzsáni 


\section{Külïgyi Szemle}

akvizíció, amelyet a járvány okozta kiutazási és kapcsolattartási ne hézségek ellenére még abban az évben sikeresen le is zárt. A válság kitörése ellenére nem állt le az INA rijekai finomítójában zajló beru házás sem, amelynek eredményeként fütőolaj helyett dízelolaj előállí tására áll át a vállalat. A járvány miatt ugyanakkor előfordultak késé sek a fejlesztésben. A MOL átmenetileg a stratégiai szempontból nem kiemelt beruházások közül néhány küllföldit is leállított.

A Covid-válság miatt nem kerültek be újabb országok a MOL tervezett beruházási helyszínei közé, az esetleges felvásárlási célpontokról pedig az információ érzékenysége miatt nem osztott meg részleteket a vállalat. A járvány hatására felértékelődött és a jövőben várhatón tovább erősödik a cég regionális szerepe, ezért kevesebb interkontinentális beruházásra lehet számítani a közeljövőben.

A válság nem befolyásolta érdemben a Richter külfö̈ldi beruhá zási stratégiáját: a cégtől kapott információk szerint a járvány miatt nem merült fel üzemek bezárása, de újabb országok sem kerültek fel a vállalat beruházási térképére, és a cég azon sem tervez változtatni, hogy mely terápiás területekre fókuszál. A világjárvány nyomán felértékelődtek a rövidebb, rugalmasabb ellátási láncok és a diverzifikált termelőkapacitások, és ez a struktúra eleve közelebb áll a Richter müködési modelljéhez, mint a hosszú, egymástól távol eső helyszínekre építő ellátási láncok.

A Tungsram öt magyarországi gyárában előállított termékek 93 szá zaléka kerül exportra, s ezt a cég több mint száz országot magában foglaló értékesítési hálózata támogatja. Mindez egy eróteljes bázist jelent a közép-európai piacoknak a regionalizáció jegyében történő ellátásához, az értékláncok rövidülése és a kereslet-kínálati viszonyok kiszámíthatatlanná válása következtében azonban a cég szerint a fej lődéshez további nemzetközi beruházások szüikségesek. Az új, Ma gyarországon kívüili gyárak létrehozása elősegítené az eddig „feltö retlen" vagy logisztikai szempontból nehezen elérhetô piacok stabil kiszolgálását és ezáltal a Tungsram piaci részesedésének a növelését. E célt szolgálhatná a folyamatban levő egyiptomi beruházás, a he lyi partnerrel közösen létrehozandó, kültéri LED-es lámpatestek 
összeszerelésével foglalkozó üzem. A beruházás nem csupán a közel keleti és észak-afrikai piacokon történő terjeszkedésre kínálna lehe tőséget, hanem kaput jelenthetne Afrikába is. A terv szerint a Magyarországról érkező, két-három alkatrészre bontott termék össze szerelése Egyiptomban történne, így a késztermékkel indulhatnának a helyi tendereken is. Az egyiptomi partnercég vezetőjének a beruházás szempontjából igen fontos magyarországi látogatása 2020 tavaszán a járvány kitörése miatt maradt el, a projekt azonban elsősorban nem ezért, hanem az árakra vonatkozó elképzelések eltérései miatt lassult le.

A válság idején az esetleges beruházási célországokban - érthető módon - nem a közvilágítás fejlesztése a rövid távú prioritás. A Tungsram ennek ellenére egy Abu-Dzabiban építendő, kültéri lámpatesteket összeszerelő üzem létrehozásában is gondolkodik, amely mellett egy agrotechnológiai bemutató farm és képzési központ is létesülne. Az összeszerelő ïzem megkönnyítené az új partnerkapcsolatok létesítését a cég kulcsfontosságú piacát jelentő régióban. A bemutató farm révén a technológiát ismertetnék meg szélesebb körben, ami új megrendeléseket hozhat. A képzési központra pedig azért van szüksége a vállalatnak, mert számos tendernél feltétel a hosszú távú jelenlét, ahhoz viszont szüikség van képzett helyi alkalmazottakra. A járvány megnehezítette a Tungsram számára a pályázat benyújtásához szükséges dokumentumok beszerzését, a korlátozások miatt a cég képviselői nem tudták személyesen felkeresni, illetve kiválasztani a helyszínt, sem találkozni a helyi partnerrel. Az abu-dzabi projektet a cég a Covid-válság ellenére meg akarja valósítani, ám az utazási korlátozások és a szociális távolságtartás esetleges fennmaradása vagy újbóli bevezetése jelentős késést okozhat.

A Master Good esetében a járványt követő első célkitûzés, hogy a Vietnamban múködő vegyesvállalat újra profitot termeljen, és a nyereségből végre lehessen hajtani a jövőbeni fejlesztéseket. A cég vezetésének a várakozásai szerint ez legalább másfél évet fog igénybe venni, vagyis a járvány ennyivel tolta ki az új beruházásokat. A vállalatnak folyamatban van egy másik küilföldi beruházási projektje is: a Master Good a HEPA pályázatán elnyert támogatás és 


\section{Külïgyi Szemle}

önerő felhasználásával Kelet-Szlovákiában, Szomotor (Somotor) köz ségben épít szójabab-feldolgozó ïzemet. A helyszínválasztásban sze repet játszott a földrajzi közelség, a magyar ajkú lakosság, illetve az a tény, hogy a szlovák gazdaságpolitika nem kezeli kiemelten a térséget, ezért a magyar cég beruházása különös jelentőséggel bír a helyiek számára. A szójafeldolgozó üzem létrehozásához kapcsolódó beruházást nem lassította a járvány, a projekt előkészítése azonban gyakori kiutazást igényel, ami nehézkesebbé és bonyolultabbá vált a határát lépési korlátozások miatt. A beruházást helyi kivitelezők végzik, a ta pasztalatok a cég szerint eddig pozitívnak mondhatók. A Covid-válság a jövőbeni beruházási tervekre sincs hatással a kelet-szlovákiai üzem esetében.

A Covid-válság alapvetően nem változtatott az Agrofeed számára releváns célpiacok listáján. A kialakult kapcsolatrendszer és a földrajzi elérhetőség miatt Oroszország mellett elsősorban Ukrajna, a FÁKtagállamok, Lengyelország, Csehország és a Balkán érdekes a cég számára. A távolabbi régiók közül a várható népességrobbanás miatt Észak- és Közép-Afrika lehet vonzó piac. A vállalat stratégiája szerint általánosságban ott lehet üzem létrehozásán gondolkodni, ahol leg alább egy műszakhoz elegendő megrendeléssel biztosan számolhat nak. A járvány ezen a stratégián nem változtatott.

\section{A Covid-válság nyomán felerösödöıt átalakulási folyamatok: ellátási láncok rövidülése, fenntarthatóság, digitalizáció}

A MOL 2050-ig terjedő víziójának a központi eleme, hogy a cégcsoport Közép- és Kelet-Európa alacsony szén-dioxid-kibocsátású körforgásos gazdaságának a kulcsszereplője legyen. Egy olaj- és gázipari vállalat számára ez nyilvánvalóan kihívás, a MOL azonban elkötelezett amellett, hogy a hagyományos, fosszilisüzemanyag-ala pú tevékenységét alacsony $\mathrm{CO}_{2}$-kibocsátású, fenntartható üzleti mo dellben múködő struktúrává alakítsa át. A cég várakozásai szerint a fenntarthatóság kritériuma egyre drasztikusabban fogja befolyásolni a tőkeberuházásokat, így célkitűzése, hogy 2025-ig 1 milliárd dollárt 
fordítson fenntartható tevékenységekre. E szempontból nem határo zott meg kiemelt célországokat, a természeti, az infrastrukturális és az üzleti adottságok befolyásolják, hogy hova fognak a fenntartható gazdasághoz köthető technológiákat telepíteni.

A digitális átalakulás a MOL-nál is folyamatban van: például fejlett adatelemzés alkalmazásával igyekeznek előre jelezni a berendezések meghibásodását, s ezzel csökkenthetôvé válik a nem várt leállások száma és a karbantartási költség.

A Tungsramnál a cégen belïli digitalizáció fejlesztése és megerő sítése folyamatos cél. Az új technológiák többek között repüléstech nikai, agrár-, illetve egészségipari termékeket érintenek, amelyek kiegészülnek a digitalizáció által meghatározott olyan területekkel, mint a létesítménygazdálkodás, az okosparkolás vagy az okosotthon. Ennek keretében a Tungsramnak lehetősége van számos, potenciálisan fejlődő iparágakba történő bekapcsolódásra, amelyek sikere további növekedést eredményezhet, vagy pótolhatja az esetlegesen leépüilő iparágak bevételkiesését. Az új technológiák és ötletek bevonzása ér dekében a cég folyamatosan bővíti a partneri hálózatát, és keresi az új együttműködési lehetőségeket a hazai és a küllöldi startupokkal, illetve kis- és középvállalatokkal. A Tungsram a vállalati átalakulás és a fenntarthatóság jegyében igyekszik egyszerre minél több piacon, az aktuális világgazdasági trendeknek megfelelő, tágabb portfólióval megjelenni, és ezáltal ellenállóvá válni az iparági átalakulás jelentette kockázatokkal és az ellátási láncok ingadozásaival szemben.

A többi céggel készített interjú során nem kaptunk olyan infor mációt, amely arra utalna, hogy a Covid-válság következményeként a fenti folyamatok növekvő mértékben határoznák meg a jövőbeni vállalati stratégiákat. 


\section{Külïgyi Szemle}

\section{Helyzetkép a magyar OFDI-t támogató állami programokról}

A magyar cégek OFDI-projektjeit támogató hazai állami programokról a Magyar Exportfejlesztési Ügynökség munkatársaival készített interjú során szereztünk információkat.

A HEPA két támogatási program révén is részt vesz a hazai cégek küllöldi tőkeberuházásainak elősegítésében. Az egyik a Nyugat-Balkán Beruházási Támogatás, amelynek célja a magyar vállalatok régiós jelenlétének és szerepének az erősítése a balkáni térségben. A vissza nem térítendő támogatásként odaítélhető forrás kedvezményezettjei hazai gazdasági társaságok, ám azt ténylegesen a küllföldi leányvállalat vagy a magyar cég többségi tulajdonában levő vegyesvállalat kapja meg. A 2021. június 15-i állapot szerint a pályázatok értékelési folyamata és a döntéshozatal lezajlott: hét projekt támogatásáról döntöttek, amelyek összértéke 7,13 milliárd forint. A nyertes projektek közül három a mezőgazdaság és az élelmiszeripar, egy-egy pedig az építőipar, a turisztikai fejlesztés, a szennyvíztisztítás és egyéb szolgáltatások területén valósul meg. A projektek kivétel nélkül Szerbiát célozzák, egy viszont Szerbia mellett Bosznia-Hercegovinára és Montenegróra is kiterjed. A HEPA-tól kapott információ szerint nem volt példa arra, hogy a Covid-válság miatt valamely cég elállt volna a beruházási szándékától, sőt a kiválasztott vállalatok közül több már meg is kezdte a projekt megvalósítását. Ugyanakkor a szerződések megkötésénél érzékelhető volt a válság hatása: elsősorban a szüikséges dokumentumok beszerzését nehezítette meg a járványhelyzet. A megvalósítás határideje egységesen 2023. december 31, amelynek a válság miatti esetleges meghosszabbítása egyelőre nem került szóba, szükség esetén arról később születhet döntés.

Kifejezetten a válság negatív hatásainak az enyhítését célozza a HEPA által kezelt, a magyar OFDI-t segítő másik program, a Küilpiaci Növekedési Támogatás (KNT). Az interjú során a HEPA jelezte, hogy mivel a program kifejezetten a válságra adott válaszként született, ezért nines kiforrott intézményi tapasztalat arról, hogy 
a krízis általánosságban hogyan hatott a magyar vállalatok külföldi beruházási hajlandóságára. A támogatást eredetileg 23 milliárd forintos keretösszegre tervezték, ám az érdeklődés mértékét látva, az összeget 71 milliárd forintra emelték. A vissza nem térítendő támogatást Magyarországon bejegyzett kis-, közép-és nagyvállalatok igényelhették, minimum 280 millió, maximum 3 milliárd forintos ösz szegben. A támogatást konzorciumi pályázók esetén a célországokban tervezett beruházásokra kell fordítani. A pályázati kírás földrajzi és iparági tekintetben is kifejezetten tágan határozta meg a támogatható OFDI-projektek körét. Az elbírálásnál a célországokat az EXIM országkockázati besorolása alapján értékelték. A beérkezett 167 pályázat közüil végüi 48-at választottak ki, a projektek földrajzi megoszlását a 4. ábra mutatja.

4. ábra

A KNT keretében kiválasztott projektek megoszlása célországonként (darab)

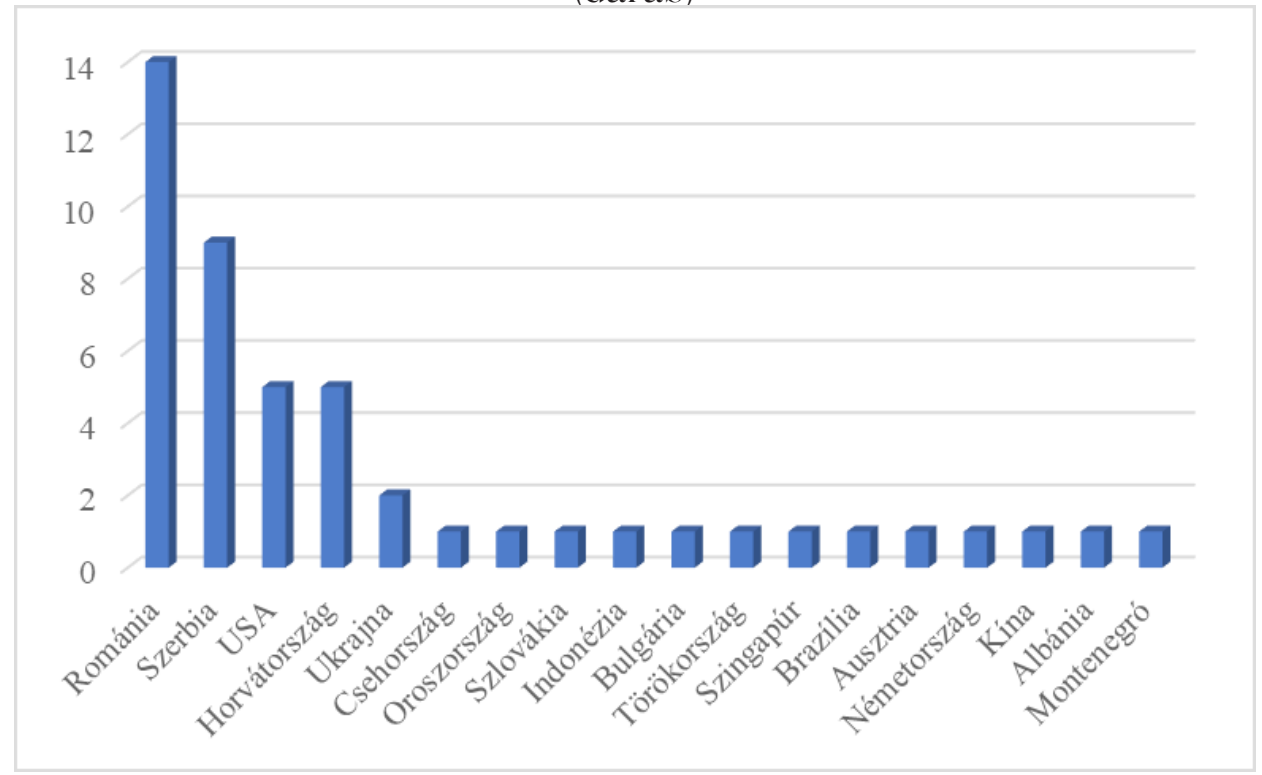




\section{Külïgyi Szemle}

Ami a szektorális megoszlást illeti, a HEPA-tól kapott információk alapján a 48 nyertes cég közül 26 gyártó projekthez venné igénybe a támogatást. Emellett többek között ingatlanprojektek, illetve áram- és gázellátáshoz, valamint víz- és szennyvízkezeléshez kapcsolódó beruházások is találhatók a listán.

A KNT-pályázat a jogszabályi elóírásoknak és a megvalósítási kockázatnak megfelelő mértékủ dokumentációs igényt támasztott a cégek felé, ám a HEPA tapasztalatai szerint a járvány jelentősen megnehezítette annak teljesítését. Elsősorban a konzorciumi partnerek elérése (például a küllföldi partnerek aláírásainak a beszerzése) bizonyult nehézkesnek; a csúszások miatt határidőket kellett módosítani, és egyszerủsítő lépések bevezetésére volt szüikség az eljárás során.

A vállalatokkal folytatott interjúkban arra a kérdésre is választ kerestünk, hogy mennyire fontos az adott cég küllföldi beruházásainak a megvalósitásában a magyar állam támogatása, és annak a jelentősége változik-e a Covid-válságot követően. A MOL esetén általánosságban elmondható, hogy inkább a beruházás jellege az, ami meghatározza, hogy egy adott FDI-projekt megvalósításához szükséges-e állami tá mogatás, nem pedig a belföldi vagy a küllföldi helyszín. A beruházá sai többségét a cég az elérhető állami támogatásoktól függetlenül is megvalósítja, ugyanakkor a válság nyomán még inkább előtérbe került, hogy a fenntartható technológiák bevezetése sok esetben csak azok mellett térül meg. Ezért az állami és az európai uniós szubven ciók szerepe várhatóan nőni fog a cég beruházási stratégiájának a megvalósításában.

A MOL-hoz hasonlóan a Richter beruházási stratégiája is független az elérhető állami támogatásoktól. A cég ennek ellenére pályázott a HEPA-nál a romániai, a lengyelországi, illetve az oroszországi üze me gyártókapacitásának a növelését célzó eszközbeszerzés támogatására.

A Tungsramtól kapott információk szerint az állami támogatás mindenképpen meggyorsítaná a küllföldi lokalizációs projektek megvalósítását, amelyeket a járvány hatásai lassítanak. 
Az Agrofeed szerint csak olyan beruházási projektben érdemes gondolkodni, amely önmagában, állami támogatás nélkül is életképes. Ugyanakkor nyilván örömmel veszik, ha a fejlesztésekhez igénybe tud nak venni állami szubvenciót, azonban csak a támogatás megszerzése érdekében nem indítanak el új beruházást.

\section{Következtetések}

A vállalati esettanulmányok alapján tehetỏ elsỏ lényeges megállapítás, hogy a megkérdezett cégek OFDI-stratégiája a Covid-válság ellenére alapvetỏen nem változott. A járvány hatásai miatt a cégek nem fordultak új beruházási helyszínek vagy piaci szegmensek felé, sôt a küllföldön folyamatban levő beruházási projektek többsége sem állt le. Talán egyedül a MOL helyzete jelent kivételt, bár az olajipari cég is csupán a stratégiainak nem minősülő beruházásait állította le átmenetileg. A minta az alacsony elemszám miatt nem tekinthető reprezentatívnak ugyan, de a HEPA-tól kapott, átfogóbb információk hasonló képet mutatnak. Kiderült belőllïk, hogy a Nyugat-Balkán Beruházási Támogatás nyertes pályázói közül az elmúlt egy évben egyetlen cég sem lépett vissza a küilföldi FDI-projektje megvalósításától. A KNT iránti hatalmas érdeklődés pedig szintén azt a megállapítást támasztja alá, hogy a magyar cégek küllföldi tőkeberuházási terveire általánosságban nem gyakorolt olyan mértékủ negatív hatást a válság, mint amilyen az UNCTAD korábban hivatkozott prognózisai alapján feltételezhető lett volna.

Mindez természetesen nem jelenti azt, hogy a világjárvány egyáltalán ne okozott volna nehézségeket a magyar cégek küllföldi termelőegységeinek a múködtetésében, illetve a folyamatban levő projektek menedzselésében. Az előbbi esetén a kiutazások, a külföldi partne rekkel való személyes találkozás lehetetlenné válása, illetve bizonyos esetekben az alapanyagok, alkatrészek beszerzése okozott problémákat. Ugyanakkor az interjúba bevont hazai vállalatok egyike sem kényszerült a külföldi üzeme bezárására vagy az alkalmazottai jelentős részének az elbocsátására, bár a kereslet csökkenése miatt a termelés 


\section{Külïgyi Szemle}

visszafogására akadt példa. Az előkészítési vagy a pályázati fázisban levő projekteknél pedig a szüikséges dokumentumok összegyújtése ment nehézkesebben a járvány miatt. Érdemes kiemelni azt is, hogy a mintában szereplő vállalatok egy része szerint a jól megválasztott helyi partner jelentősége tovább nôtt a válság során, a kiutazások és a kapcsolattartás nehezebbé válása miatt pedig a küllföldi termelöüzem vezetőjének a szerepe értékelődött fel még jobban.

Az interjúk során a digitalizációt és a fenntarthatóság előtérbe kerülését illetően kapott, meglehetősen kevés információ alapján inkább csak valószínúsíthető, hogy az OFDI-ban érdekelt hazai cégek esetében a válság önmagában nem gyorsítja fel látványosan ezeket az átalakulási folyamatokat. East és Kaspar (2020), továbbá az IBM (2021) megállapításai - amelyek szerint a válságot követően nem lesz visszatérés a korábbi üzletmenethez - nem, illetve csak korlátozottan köszöntek vissza a magyar cégekkel készített interjúkban. Ennek oka az lehet, hogy a Richter esetében egy, a válság által viszonylag kevéssé érintett, speciális iparágról van szó, a MOL szintén nem tekinthető hagyományos gyártó vállalatnak, a másik három cég pedig a kisebb méretéből adódóan vélhetően csak fokozatosan veszi át a jövőben az Ipar 4.0-hoz köthető új ellátásilánc-technológiákat.

Ami a Covid-válság nyomán felgyorsult egyéb változásokat illeti, érdekes összevetni East és Kaspar (2020) elemzésének a megállapítását - hogy a pandémia felerősíti az értékláncok regionális jellegét - a magyar OFDI célországaival. Ahogyan a KNT keretében kiválasztott projektek megoszlása is mutatja, a magyar OFDI - az Amerikai Egyesült Államok kivételével - továbbra is elsősorban a kör nyezô országokat célozza. Mindez egybecseng az MNB korábban hi vatkozott adataival, amelyek azt mutatják, hogy a magyar OFDI célor szágai alapvetően nem változtak a válság hatására. A regionális jelleg ugyanakkor inkább a hazai cégek földrajzi „hatósugarának” tudható be, nem pedig az értékláncok átalakulási folyamatainak. Az UNCTAD (2021a) azon megállapítása azonban, hogy a cégek részéről új ellátási láncok építése helyett az értékláncmenedzsment hatékonyabbá tétele a valószínúbb reakció a válságra, a küilföldi termelőegységeket múködtető 
magyar vállalatok esetében is érvényes lehet. Az interjúk során szóba került logisztikai és alkatrészbeszerzési nehézségek legalábbis arra ösztönözhetik a vállalatokat.

A digitalizáció és a fenntarthatóság folyamataihoz hasonlóan, a válság az állami támogatások iránti igény terén sem hozott látványos változást. A megkérdezett vállalatok szerint a válság nem tette az elérhető állami támogatások függvényévé a jövőbeni küllföldi beruházási terveiket. Ezzel együtt utaltak arra, hogy a megfelelő állami szerepvállalás meggyorsíthatja egyes projektek megvalósítását, ám azoknak a támogatástól függetlenül is múködőképesnek kell lenniük. A válság nyomán még inkább előtérbe került, a fenntartható energiához köthető technológiák megtérülésében ugyanakkor kiemelt szerepük lehet az állami támogatásoknak a jövőben.

\section{Irodalomjegyzék}

Almadi Sejla (2018). Can the V4's Priorities Shape "Europe's Priorities"? The Multiannual Financial Framework 2021-2027. EUROPEUM Instilute for European Policy. A letöltés ideje: 2021. május 15. http://www.europeum. org/data/articles/5-sejla.pdf.

Báger Gusztáv és Parragh Bianka (2020). A koronavírus-válság, a fenntartható

fejlődés és az ösztönző állam modellje. Pénzügyi Szemle, (2), 86-113.

Dencik, Jacob, Gijpers, Koen, Spee, Koel, van Hove, Patsy és Zaharchuk,

David (2020). IBM Research Insights - Global Location Trends, 2020

Special Edition: Location Strategy in a Post-COVID-19 World. A letöltés ideje: 2021. július 15. https:/www.ibm.com/downloads/cas/2M3LVRXO. East, David és Kaspar, Martin G. (2020). The Impact of COVID-19 on Manufacturing Investments. UNIDO Industrial Analylics Plalform. A letöltés ideje: 2021. április 15. https:/iap.unido.org/articles/impactcovid-19-manufacturing-investments $\#$ fn-448-0.

Eurostal (2021). Impact of Covid-19 Crisis on Industrial Production. A letöltés ideje: 2021. július 19. https://ec.europa.eu/eurostat/statisticsexplained/index.php?title=Impact of Covid-19_crisis_on_industrial production\#Recent development of industrial production.

Fang, Ying, Collins, Alan és Yao, Shujie (2021). On the Global COVID-19 Pandemic and China's FDI. Journal of Asian Economics, 74, 1-16. 


\section{Külïgyi Szemle}

IBM (2021). How to Invest Now to Expedite Covid-19 Recovery. A letöltés ideje: 2021. június 30. https://www.ibm.com/thought-leadership/ institute-business-value/report/covid-19-recovery\#.

International Labour Organization (2021). Covid-19 and the World of Work. Sectoral Impact, Responses and Recommendations. A letöltés dátuma: 2021. május 15. https://www.ilo.org/global/topics/coronavirus/sectoral/ lang--en/index.htm.

KSH (2021). A vállalkozások teljesítménymutatói létszámkategória szerint.

A letöltés ideje: 2021. június 23. https://www.ksh.hu/stadat files/gsz/hu/ gszOO17.html.

Kumar, Aalok, Luthra, Sunil, Mangla, Sachin K. és Kazançoğlu, Yiğit (2020). COVID-19 Impact on Sustainable Production and Operation Management, Sustainable Operations and Computers, (1), 1-7.

McKinsey (2021). Covid-19 - Implications for Business. A letöltés ideje: 2021. június 23. https://www.mckinsev.com/business-functions/risk/ our-insights/covid-19-implications-for-business.

MNB (2021). BMP6 módszertan szerinti adatok. A letöltés dátuma: 2021. június 1. https:/www.mnb.hu/statisztika/statisztikai-adatokinformaciok/adatok-idosorok/viii-fizetesi-merleg-kozvetlentokebefektetesek-kulfolddel-szembeni-allomanyok/kozvetlentokebefektetesek/bpm6-modszertan-szerinti-adatok.

OECD (2020). Foreign Direct Investment Flows in the Time of COVID-19. A letöltés ideje: 2020. május 10. https://read.oecdilibrary.org/view/?ref $=132+132646-\mathrm{g} 8$ as $4 \mathrm{msdp} 9 \&$ title $=$ Foreigndirect-investment-flows-in-the-time-of-COVID-19\&$\mathrm{ga}=2.83135696 .710139430 .1624966432-1850102531.1624275549$.

Shukla, Smita és Bansal, Megha (2020). The Impact of COVID-19 on the Outward Foreign Direct Investment (OFDI) by Indian Companies. Ahmedabad: Nirma University Institute of Management.

Túróczi Imre, Mester Éva és Zéman Zoltán (2020). Magyarország Versus Covid-19: intézkedések, tapasztalatok, jövőkép. Polgári Szemle, 6(1-3), $78-93$.

UNCTAD (2020a). Investment Trends Monilor, March 2020, Special Issue. Genf: United Nations.

UNCTAD (2020b). World Investment Report 2020, International Production Beyond the Pandemic. Genf: United Nations. 
UNCTAD (2021a). World Investment Report 2021, Investing in Sustainable Recovery. Genf: United Nations.

UNCTAD (2021b). Investment Trends Monitor, January 2021, Issue 38. Genf: United Nations.

UNCTAD (2021c). World Investment Report, Annex Tables. A letöltés ideje: 2021.07.16. https://worldinvestmentreport.unctad.org/annex-tables/. 